\title{
TRANSFORMASI PENCAK SILAT PARIAN MENJADI TARI GARIGIAK DI ISTANO TUAN GADANG BATIPUAH KECAMATAN BATIPUAH KABUPATEN TANAH DATAR
}

\author{
Auliana Mukhti Maghfirah ${ }^{1^{*}}$, Erlinda $^{2 *}$ \\ Minat Studi Pengkajian Seni Tari Program Pascasarjana \\ Institut Seni Indonesia Padangpanjang \\ Jl. Bahder Johan, Guguak Malintang, Padangpanjang, Kota Padangpanjang, 27126. \\ Sumatera Barat. Indonesia \\ Email: auliana.muthy@yahoo.com
}

\begin{abstract}
Abstrak
Tari Garigiak adalah satu bentuk seni pertunjukan tradisi di Istano Tuan Gadang Batipuah Kabupaten Tanah Datar, yang gerak tarinya bersumber kepada gerakan Silek Parian. Silek Parian merupakan seni beladiri yang berkembang di Nagari Baipuah Ateh yang di akuui oleh masyarakat keberadaan tari tersebut. Oleh karenanya tari Garigiak diakui pula sebagai produk budaya asli Kecamatan Batipuah, yang memiliki makna khusus dalam kehidupan masyarakat pendukungnya. Tari Garigiak, memiliki gaya gerak yang tidak jauh berbeda dari Silek Parian itu sendiri. Karena bila gaya Silek Parian masih memperlihatkan gaya beladiri yang berbentuk fisik maupun penyaluran tenaganya seperti pertarungan, namun dalam tarian ditampilkan terlihat lebih indah karena sudah mengalami proses stilisasi. Dengan demikian kesenian tradisional tari Garigiak dapat dikatakan sebagai hasil dari proses kreativitas, berupa produk baru yang diciptakan oleh keturunan Tuan Gadang Batipuah. Meskipun secara teks merupakan adaptasi dari Silek Parian. Tujuan penelitian ini untuk melihat faktor penyebab terjadinya transformasi dalam Silek Parian menjadi tari Garigiak di Kecamatan Batipuah. Metode yang digunakan adalah metode kualitatif, pengumpulan data dilakukan melalui observasi dan mengamati kesenian tradisional khususnya tari tari Garigiak, dokumentasi audio dan visual serta wawancara dengan sejumlah tokoh adat dan masyarakat. Penelitian ini dianalisis dengan teori bentuk, teori fungsi dan teori kreativitas. Secara umum, penelitian ini memperoleh hasil berupa sejauh mana kreativitas dan perwujudan gerak Silek Parian dalam kesenian tradisional masyarakat di Nagari Batipuah ateh yang terfokus pada tari Garigiak.
\end{abstract}

Kata Kunci: Silek Parian, tari Garigiak, masyarakat.

\begin{abstract}
Garigiak dance is a form of traditional performing arts at Istano Tuan Gadang Batipuah Tanah Datar District, whose dance moves are sourced from the Silek Parian movement. Silek Parian is a martial art that developed in Nagari Baipuah Ateh which was acknowledged by the community where the dance was. Therefore Garigiak dance is also recognized as a genuine cultural product of the Batipuah District, which has special meaning in the lives of its supporting communities. Garigiak dance, has a style of motion that is not much different from the Silek Parian itself. Because if the style of Silek Parian still shows a self-defense style in the form of physical as well as channeling its energy like a fight, in the dance it appears to look more beautiful because it has undergone a stylization process. Thus the traditional arts of Garigiak dance can be said to be the result of the process of creativity, in the form of new products created by the descendants of Tuan Gadang Batipuah. Although text is an adaptation of Silek Parian. The purpose of this study was to look at the causes of the transformation in the Silek Parian into the Garigiak dance in Batipuah District. The method used is a qualitative method, data collection is done through observation and observing traditional arts, especially Garigiak dance, audio and visual documentation and interviews with a number of traditional leaders and the community. This research was analyzed by form theory, function theory and creativity theory. In general, this research obtained results in the form of the extent of the creativity and manifestation of the movement of Silek Parian in the traditional arts of the people in Nagari Batipuah ateh which focused on the Garigiak dance.
\end{abstract}

Keywords: Silek Parian, Garigiak dance, society. 


\section{PENDAHULUAN}

Pencak silat merupakan seni beladiri khususnya di Minangkabau yang telah berusia cukup lama dan masih berkembang sampai saat ini. Pencak silat terdiri dari dua suku kata yaitu pencak dan silat. "Pencak" lebih mengedepankan unsur seni dan penampilan keindahan gerakan dengan musik serta busana tradisional, sedangkan "silat" adalah inti ajaran beladiri dan bertarung. Setiap daerah memiliki bahasa ataupun penamaan masing-masing, dimana pencak silat disebut silek oleh masyarakat Minangkabau untuk memberikan ciri khas dengan nama yang berbeda.

Silek di Minangkabau memiliki beberapa aliran salah satunya Silek Parian yang merupakan salah satu silek yang ada di Jorong Balai Sabuah yang berasal dari Nagari Pariangan. Parian adalah suatu alat yang terbuat dari bambu, biasanya alat ini digunakan masyarakat setempat sebagai alat pembawa air dari pincuran ke rumah untuk kebutuhan sehari-hari, seperti minum, memasak nasi, dan bahkan untuk mandi. Namun dalam Silek Parian, alat ini digunakan sebagai pengganti senjata untuk menghadapi lawan, sehingga silek yang ada di Batipuah Ateh tersebut terkenal dengan nama Silek Parian, oleh masyarakat Jorong Balai Sabuah parian disebut juga garigiak.

Gerakan Silek Parian ini merupakan sumber cipta pada masyarakat di Kecamatan Batipuah Kabupaten Tanah Datar khususnya. Hal ini tampak pada salah satu tarian yang ada di Istano Tuan Gadang Batipuah di Kecamatan Batipuah Kabupaten Tanah Datar yaitu tari Garigiak. Tarian ini terdiri dari empat gerak yaitu, gerak sambah, gerak seka, gerak manuntuang, dan gerak mananan. Sedangkan Silek Parian terdiri dari tujuh jurus, yaitu sambah, pancuang sauleh, sauak aia, cucuak tigo liang, sandaran parian, guliang, seka.

Rafael Raga Maran mengatakan bahwa, dalam sebuah kreatifitas kegiatan tersebut tidak terlepas dari kebudayaan dan kreatifitas masyarakat setempat, demikian juga tari menghasilkan nilai-nilai kreatif tidak terlepas dari masyarakat pendukung, rutinitas, maupun lingkungan sendiri (Rafael, 2000:52). Hal demikian mengungkapkan gagasan atau perasaan manusia melalui bentuk karya, diantaranya adalah dalam bentuk karya seni tari yaitu tari Garigiak yang ada di Jorong Balai Sabuah Nagari Batipuah Ateh. Berdasarkan pernyataan diatas tari Garigiak merupakan hasil kreativitas anak kemenakan Tuan Gadang Batipuah serta Masyarakat setempat.
Perkembangan seni ditentukan oleh corak masyarakat menyangkut kebutuhan dan kemudahan - kemudahan didalam masyarakat. Dalam hal ini yang menentukan ekspresi seni adalah : (1) tradisi - tradisi terdahulu baik yang menyangkut kemahiran teknik maupun anggapan - anggapan yang telah mengakar ; (2) kebutuhan - kebutuhan yang dirasakan ; (3) keadaan lingkungan baik yang alamiah; (4) taraf intensitas komunikasi dengan lingkungan atau masyarakat lain. Keempat faktor tersebut saling terakait satu sama lainnya dan saling mempengaruhi atau dipengaruhi (Sedyawati, 1987:8). Tarian ini dahulunya hanya ditarikan di dalam Gaduang dalam acara adat untuk penyambutan tamu, dan tarian ini hanya ditarikan oleh anak kemenakan Tuan Gadang Batipuah.

Berdasarkan penjelasan diatas, dapat disimpulkan, ada beberapa rumusan masalah untuk mengungkap penyebab terjadinya trasformasi silek parian menjadi tari garigiak di kecamatan batipuah kabupaten tanah datar, rumusan masalah dari penelitian ini yaitu:

1. Sejauh mana konsep silek Parian dalam proses pertumbuhan dan perkembangan kesenian tradisional masyarakat Nagari Batipuah Ateh terkhusus tari Garigiak?

2. Apa faktor-faktor penyebab terjadinya transformasi silek Parian menjadi seni pertunjukan tari Garigiak di Iatano Tuan Gadang Batipuah?

Tujuan dari penelitian ini adalah untuk mengetahui:

1. Bentuk silek Parian serta asal usul silek Parian di Istano Tuan Gadang Batipuah

2. Bentuk perubahan dan kreativitas dalam silek Parian menjadi tari Garigiak yang terdapat di Istano Tuan Gadang Batipuah.

\section{KAJIAN TEORI}

Pemecahan dari masalah tersebut diperlukan pendapat teori-teori yang berkaitan yaitu Soedarsono, yang menjelaskan bahwa fungsi seni pertunjukan dalam kehidupan masyarakat menempatkan salah satu bentuk seni pertunjukan yang lebih penting dari masyarakat yang lain, dan ada dua fungsi utama dari tari yaitu untuk tujuan-tujuan magis dan sebagai tontonan (Soedarsono, 2002:121). Sedangkan Mursal Esten mengatakan suatu bentuk kesenian akan bisa hidup dan berkembang apabila kesenian tersebut dibutuhkan masyarakatnya. Apabila masyarakat tidak membutuhkan lagi maka mustahil kesenian itu akan hidup dan berkembang apapun usaha yang dilakukan untuk perkembangannya (Mursal, 1993:52). Untuk mengkaji munculnya produk baru dengan pijakan dari budaya yang sudah ada maka digunakan teori adaptasi 
oleh Julie Sandres. Teori adaptasi digunakan untuk mengkaji bagaimana proses terbentuknya budaya baru yang diakibatkan oleh proses adaptasi tersebut. Teori adaptasi ini didukung dengan teori cultural appropriation, untuk menunjukan bahwa suatu kebudayaan barumuncul karena ada proses peminjaman budaya dari budaya lain (Sandres, 2006: 2-3).

\section{METODE PENELITIAN}

Metode penelitian merupakan suatu cara atau teknik dalam mencapai tujuan dari penelitian. Penelitian ini bersifat kualitatif menggunakan metode deskriptif analisis, dimana memfokuskan kepada objek tari Garigiak yang merupakan manifestasi dari gerak Silek Parian yang ada di Istano Tuan Gadang Batipuah. Tahap pengumpulan data yang penulis lakukan adalah dengan cara mencari sumber-sumber dan referensi yang ada pada buku cetak, jurnal, dan laporan skripsi yang mengacu pada pembahasan penelitian dengan mengawali turun langsung ke lapangan untuk melakukan survey mengenai objek yang akan diteliti. Peneliti bertemu langsung dan melakukan wawancara dengan beberapa narasumber yang mengetahui lebih jelas tentang Silek Parian sekaligus tari Garigiak. Wawancara dilakukan kepada nara sumber yang diawali dari informasi yang didapat dari masyarakat yang ada disana. Menyiapkan kisi-kisi pertanyaan yang akan diajukan kepada nara sumber yang didasari kepada relevansinya dengan objek kajian penulis yaitu tari Garigiak. Wawancara dilakukan secara formal dan informal, sengaja atau tidak disengaja dan dibantu dengan handphone. Data yang telah dikumpulkan dari hasil wawancara maupun referensi yang didapat pada tahap berikutnya akan dipilah-pilah dan disusun berdasarkan keperluan penulisan hingga akhirnya menjadi sebuah laporan tertulis sesuai dengan sistematis penulisan laporan penelitian.

\section{HASIL DAN PEMBAHASAN}

\section{Hasil}

Minangkabau merupakan daerah yang memiliki ragam budaya, keberagaman seni tersebut hadir dan dikembangkan oleh masyarakat pemiliknya. Salah satunya Nagari Batipuah Ateh, khususnya Jorong Balai Sabuah memiliki beragam jenis kesenian diantaranya Randai, tari Gadih Basanai, tari Bangkiah, tari Piriang, tari Garigiak dan Silek.

Tradisi silek diturunkan secara lisan yang menyebar dari mulut kemulut dan diajarkan dari guru ke murid, sehingga catatan tertulis mengenai asal mula silek sulit ditemukan. Silek selain ilmu beladiri, juga merupakan sarana pendidikan yang dilakukan turun temurun oleh
Gorga Jurnal Seni Rupa

Volume 08 Nomor 01 Januari-Juni 2019

p-ISSN: 2301-5942 | e-ISSN: 2580-2380

kaum, suku, dan rumah gadang. Silek sebelum Agama Islam masuk ke ranah Minangkabau merupakan beladiri yang tidak hanya sekedar melumpuhkan lawan tetapi juga mematikan, maka dari itu jarang diperlihatkan secara umum. Setiap guru silek yang mengajar ditempat umum selalu mendapatkan lawan, sehingga tempat latihan silek dinamakan sasaran dikarenakan tempat latihan silek ditempat semestinya atau tempat yang tepat. Tempat tersebut diantaranya, rumah gadang, kandang peliharaan, parak, atau hutan yang jauh dari pemukiman penduduk. Di samping itu dalam perkembangannya, beladiri pencak silat tidak lagi hanya sebagai pertahanan diri tetapi telah menjdi salah satu cabang olahraga yang dipertandingkan.

Silek yang berasal dari Jorong Balai Sabuah ini adalah silek Parian yang merupakan seni tradisi masyarakat Nagari Batipuah Ateh Kabupaten Tanah Datar yang merupakan salah satu budaya non bendawi. Silek Parian dibawa oleh rombongan Tuan Gadang Batipuah dari Pariangan Koto Batu ke Nagari Batipuah. Hadirnya silek Parian memiliki peran penting di tengah masyarakat dalam pembentukan karakter generasi muda yang lebih baik dan merupakan sumber cipta produk kesenian baru di Istano Tuan Gadang Batipuah seperti tari Garigiak.

Menurut masyarakat setempat gerak tari Garigiak ini bersumberkan dari gerak silek Parian yang berkembang di Kecamatan Pariangan Kabupaten Tanah Datar. Dikatakan silek Parian adalah, karena silat tersebut menggunakan parian sebagai senjata dalam melawan musuh yang datang. Parian adalah suatu alat yang terbuat dari bambu, biasanya alat ini digunakan masyarakat setempat sebagai alat pembawa air dari pincuran ke rumah untuk kebutuhan seharihari, seperti minum, memasak nasi, dan bahkan untuk mandi. Namun dalam silek Parian, alat ini digunakan sebagai pengganti senjata untuk menghadapi lawan, sehingga silek yang ada di Batipuah Ateh tersebut terkenal dengan nama silek Parian, oleh masyarakat Jorong Balai Sabuah parian disebut juga garigiak.

Tari Garigiak adalah sebuah pertunjukan tari yang geraknya menggunakan properti garigiak. Pertunjukan tari tersebut menggambarkan kehidupan masyarakat pendukungnya yaitu aktivitas sehari-hari dalam mengambil air dari pincuran ke rumah masingmasing. Dalam pertunjukannya, garigiak selalu digunakan pada setiap gerak tari tersebut sehingga tari ini dikenal dengan tari Garigiak. 


\section{Pembahasan}

Kerajaan minangkabau yang menganut sistim matrilineal atau menurut garis keturunan ibu, dan dipimpin oleh rajo tigo selo beserta ampek basa ampek balai - lima dengan tuan gadang batipuah. Merupakan kelanjutan perwujudan suatu perjalanan masa atau suatu perjalanan kurun waktu sebuah kerajaan tertua yang pertama di Alam Minangkabau ini, yaitu yang terletak di Pariangan. Adapun kerajaan tertua tersebut adalah kerajaan Pasamayam Koto Batu di Lagundi Nan Baselo Pariangan. Pada masa kekuasaan itu hanya mempunyai dua buah suku di dalam kerajaan tersebut, yaitu suku melayu dan suku koto.

Pada saat pusat kerajaan Pasamayam Koto Batu di Langgundi Nan Baselo Pariangan, dipimpin oleh Tuan Gadang dengan gelar Datuak Pamuncak Alam. Setelah berjalannya beberapa waktu ke waktu, timbullah niat yang akhirnya merupakan suatu keputusan untuk memeperluas daerah serta mengembangkan sistem yang telah ada dalam struktur kepemerintahan kerajaan ke daerah sebelah matohari mati.

Setelah daerah tersebut ditempati dibawah kepemimpinan Datuak Pamuncak Alam ( setelah itu bergelar Tuan Gadang batipuah). Maka terbuatlah sebuah nagari yang diberi nama Nagari Batipuah dan didirikanlah sebuah kerajaan yang disebut dengan Istano Tuan Gadanag Batipuah. Tanggal 24 Februari 1841, merupakan hal yang paling bersejarah dimana pada hari tersebut terjadi awal perang Batipuh. Dimana terjadilah serangan mendadak oleh pasukan Tuan Gadang Batipuh terhadap gudang senjata pemerintah Belanda di Guguak Malintang Padangpanjang.

Pada tahun 1959 ( semasa pemberontakan PRRI) terjadilah pembalasan serangan balik dan di bakarnya Istano Tuan Gadang Batipuah di Jorong Balai Sabuah Nagari Batipuah Ateh, dan dari sinilah lahirnya tari Garigiak yang mana merupakan transformasi dari silek Parian yang merupakan beladiri bambu runcing pada saat tersebut. Parian merupakan empat ruas bambu yang digunakan masyarakat Jorong Balai Sabuah khususnya, sebagai alat pembawa air dari pincuran untuk kebutuhan sehari-hari, yang mana alat ini disebut dengan nama Garigiak oleh masyarakat Batipuah.

Silek Parian adalah seni beladiri murni, sehingga setiap gerak mempunyai tujuan. Aspek keindahan gerak dalam konteks seni beladiri hanya efek dari gerak yang dilakukan secara maksimal. Gerak dalam silek Parian membutuhkan tenaga yang relative besar, karena jika tidak maka tidak akan menimbulkan efek karena lahirnya silek merupakan latar belakang dari pertahanan diri. Selain merupakan beladiri, juga merupakan sumber cipta kesenian tari Garigiak di Istano Tuan Gadang Batipuah. Lahirya tari ini merupakan wujud rasa kasihan terhadap kesedihan Tuan Gadang Batipuah pada masa terbakarnya Istano Tuan Gadang Batipuah. Melihat latihan silek yang dilakukan pasukan Tuan Gadang Batipuah setiap malamnya dengan sembunyi-sembunyi, menimbulkan inspirasi anak kemanakan Tuan Gadang Batipuah untuk menciptakan sebuah karya baru untuk menghibur Tuan Gadang Batipuah.

Untuk mengkaji munculnya produk baru dengan pijakan dari budaya yang sudah ada maka digunakan teori adaptasi oleh Julie Sandres. Teori adaptasi digunakan untuk mengkaji bagaimana proses terbentuknya budaya baru yang diakibatkan oleh proses adaptasi tersebut. Teori adaptasi ini didukung dengan teori cultural appropriation, untuk menunjukan bahwa suatu kebudayaan barumuncul karena ada proses peminjaman budaya dari budaya lain. Teori adaptasi digunakan untuk melihat transformasi yang terjadi dalam silek Parian menjadi tari Garigiak yang ditampilkan di dalam acara-acara adat yang dihadirkan di dalam Gaduang. Hal ini dapat dilihat dengan penggunaan gerak, iringan, dan properti pada tari garigiak yang diambil dari gerak, iringan, dan properti beladiri silek Parian. Sedangkan kostum yang digunakan dalam tari Garigiak sangatlah berbeda dengan kostum silek Parian.

Melihat kelincahan dan keindahan langkah-langkah silek Parian, muncullah keinginan dan inspirasi pencipta melahirkan sebuah kesenian baru yang disusun rapi sehingga terbentuklah produk baru yang diberi nama tari Garigiak.. Tari Garigiak tidak jauh berbeda dengan silek parian, yang mana sama-sama menggunakan properti bambu, hanya saja dalam silek parian merupakan senjata namun dalam tarian merupakan properti yang disebut Garigiak. Jika diperhatikan gerak tari Garigiak tidak jauh berbeda dengan silek Parian, bila silek Parian menggunakan tenaga maka tari Garigiak lebih mengutamakan keindahan karena geraknya sudah di stilisasi.

Sebagaimana yang telah dijelaskan sebelumnya, bahwa gerak tari Garigiak merupakan gerak tari yang berakar dari gerak pencak silat yang tumbuh dan berkembang di Istano tuan Gadang Batipuah yaitu silek Parian. Tari Garigiak dan silek Parian tidak bisa dipisahkan dikarenakan sangat berkaitan erat. Silat merupakan gerak yang digunakan dalam 


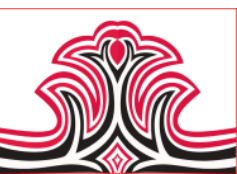

pertarungan dan beladiri sesungguhnya. Sedangkan pencak merupakan gerak yang digunakan untuk melatih kelenturan, namun tari jika gerakannya digunakan untuk mendapatkan kenikmatan dari keindahan bentuknya. Bila diperhatikan tari Garigiak merupakan gerak yang di ambil dari gerak silek Parian yang dikembangkan menjadi sebuah tarian. Akan tetapi sudah mengalami penambahan, pengurangan, dan perubahan ke aliran lain.

Berkaitan dengan bentuk, tari Garigiak memiliki elemen-elemen tari secara utuh seperti rangkaian gerak yang mencerminkan aktivitas sehari-hari masyarakat Jorong Balai Sabuah. Seperti yang disampaikan Y. Sumandiyo Hadi, "bahwa bentuk merupakan wujud yang diartikan sebagai hasil dari berbagai elemenelemen tari tari yaitu gerak, musik, kostum, rias, properti, penari dan tempat pertunjukan" (Sumandiyo, 2007:24). Suatu bentuk pertunjukan tari tidak terlepas dari aspek-aspek yang mendukungnya. Begitu juga dengan pertunjukan tari Garigiak di Istano Tuan Gadang Batipuah, bahwa keutuhan elemen-elemen tersebut mengambarkan bentuk pertunjukan tari secara keseluruhan.

Tari Garigiak merupakan sebuah karya seni yang muncul di Istano Tuan Gadang Batipuah mengindikasikan adanya proses adaptasi dan apropriasi dari silek Parian. Tari Gariggiak merupakan produk hasil dari apropriasi yang masih mempertahankan bentuk silek Parian karena hasi dari proses adaptasi silek Parian. Berdasarkan keterangan di atas terlihat adanya terjadi transformasi pada silek Parian yang terbagi atas tekstual dan kontekstual. Sehingga pada tekstual dikaji dengan teori adaptasi karena tari Garigiak masih mempertahankan bentuk silek Parian. Sedangkan kontekstual dikaji dengan teori apropriasi.

Secara teks silek Parian mengalami perubahan pada bentuk pertunjukannya, seperti gerak, kostum, tempat pertunjukan, dan waktu pertunjukan. Namun dalam tari Garigiak tetap mempertahankan dasar gerak silek Pariannya dan properti yang digunakan sebagai senjata untuk beladiri yang menjadikan salah satu ciri khas yang membuat berbeda dengan aliran silek lainnya.

Jika dilihat dari analisis konteksnya, silek Parian merupakan salah satu aliran silek yang murni sebagai pertahanan diri terhadap apapun serangan yang datang, baik dari alam dan lingkungan sekitar. Transformasi tidak hanya terjadi pada bentuknya saja, melainkan juga fungsi dan makna yang terkandung didalamnya. Seperti pada awalnya ketika sudah
Gorga Jurnal Seni Rupa

Volume 08 Nomor 01 Januari-Juni 2019

p-ISSN: 2301-5942 | e-ISSN: 2580-2380

menjadi sebuah tarian Istano tarian ini dahulunya berfungsi sebagai hiburan pada acara-acara adat yang dihadirkan di dalam gaduang Tuan Gadang Batipuah, seperti yang dikatakan Soedarsono bahwa seni pertunjukan dalam kehidupan masyarakat menempatkan salah satu bentuk seni pertunjukan yang lebih penting dari masyarakat yang lain, dan ada dua fungsi utama dari tari yaitu untuk tujuan-tujuan magis dan sebagai tontonan (Soedarsono, 2002:121). Namun tarian ini pada awalnya tari hiburan untuk kerajaan, hanya saja seiring berjalannya waktu tarian ini sudah ditampilkan diluar gaduang (ganti Istano yang dibakar) dan sudah menjadi hiburan rakyat. Dalam hal ini gerakan tari Garigiak merupakan hasil transformasi dari gerakan silek Parian yang distilisasi oleh penciptanya sehingga melahirkan sebuah produk baru yaitu karya seni yang menghasilkan estetika atau keindahan. Terkait dengan konteks suatu karya harus memiliki estetika, baik estetika beladiri pada silek Parian dan estetika seni tari pada tari Garigiak yang membedakan antara tari dan beladiri.

\section{KESIMPULA DAN SARAN}

\section{Kesimpulan}

Berdasarkan penelitian yang dilakukan, tari Garigiak merupakan transformasi gerak yang diadaptasi dari jurus silek Parian yang mengalami perubahan, penambahan, serta pengurangan gerak. Jika silek Parian menggunakan tenaga, maka tari Garigiak lebih mengutamakan keindahan karena geraknya sudah mengalami proses stilisasi dan proses distorsi. Proses ini dilakukan untuk memdapatkan sebuah hasil garapan baru yang memiliki estetika yang diinginkan.

Bentuk transformasi yang terjadi dalam silek Parian mempunyai bentuk tersendiri, hal ini dikarenakan gerak-geraknya sudah memiliki komposisi gerak dan estetika yang tidak lagi berben 78 rus melainkakan sudah tertata membentuk suatu koreografi. Dilihat secara kontekstualnya, transformasi yang terjadi yaitu perubahan fungsi serta makna dari beladiri menjadi hiburan. Perubahan estetika dalam tari Garigiak sangat terlihat jelas jika dalam garapannya ada gerak berpasangan seperti pertarungan, namun disini memiliki estetika yang berbeda sehingga ada suatu kenikmatan yang didapatkan oleh si penonton.

\section{Saran}

Berkaitan dengan penelitian Transformasi pencak silat Parian menjadi tari Garigiak Di Istano Tuan Gadang Batipuah Kecamatan Batipuah Kabupaten Tanah Datar, penulis berharap pemerintah untuk tetap berperan terhadap kebudayaan yang ada di nagari 


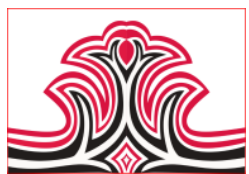

Batipuah Ateh khususnya tari Garigiak, hendaknya juga dijadikan sebagai promosi pariwisata di Kabupaten Tanah Datar. Kepada generasi penerus yang ada di nagari Batipuah ateh untuk tetap mencintai dan melestarikan tari Garigiak sebagai salah satu kebudayaan yang mereka miliki. Karena tarian ini merupakan kesenian yang bersejarah yang hadir pada masa perperangan PRRI yang menjadi tarian Istano bagi Keluarga Besar Tuan Gadang Batipuah.

\section{DAFTAR RUJUKAN}

Edi Sedyawati. (1987). Peranan Arkeologi Dalam Studi Sejarah Kesenian Indonesia, Jakarta: Pusat Penelitian Arkeologi Nasional.

Esten, Mursal.(1993). Minangkabau Tradisi dan Perubahan. Padang: Angkasa Raya.

Rafael Raga Maran. (2000). Manusia dan Kebudayaan dalam Perspektif Ilmu Budaya dasar. Jakarta: PT. Rineka Cipta.

Sandres, Julie. (2006). Adaptation and appropriation New Critical Idiom. USA \& Canada: Routledge.

Soedarsono. (2002). Seni Pertunjukan Indone sia di Era globalisasi. Yogyakarta: Gajah Mada University Press.

Sumandiyo Hadi. (2007). kajian tari teks dan konteks. Yogyakarta: Pustaka Book Publisher. 